\title{
Comment on "Application of Struvite Alters the Antibiotic Resistome in Soil, Rhizosphere, and Phyllosphere"
}

$\mathrm{P}$ hosphate fertilizers are essential to grow crops that are needed to feed everyone on our planet. The primary fossil resource phosphate rock is, however, finite and its current linear use is creating one of the biggest global environmental concerns (eutrophication), which demands immediate action. ${ }^{1}$ To stay within the planetary boundaries and target the United Nations' Sustainable Development Goals, the development and implementation of phosphorus recovery and recycling techniques is essential in order to realize a circular phosphorus economy. ${ }^{1,2} \mathrm{~A}$ promising way to recover phosphates is by the precipitation of struvite $\left(\mathrm{MgNH}_{4} \mathrm{PO}_{4} \cdot 6 \mathrm{H}_{2} \mathrm{O}\right)$ from phosphorus and nitrogen rich waste streams, such as manure, municipal wastewater, and wastewater from food production, simply by the addition of magnesium salts (typically $\mathrm{MgCl}_{2}$ ). A variety of struvite production processes are available that, also depending on the feedstocks used and the process conditions applied (e.g., washing and filtration steps, granule size, and the amount of $\mathrm{MgCl}_{2}$ added), afford struvite with differing quality. ${ }^{3,4}$ For example, the $\mathrm{P}_{2} \mathrm{O}_{5}$-content of struvite precipitated with several technologies from municipal wastewater can range from 14.7 to $30.5 \%$ (Table 1). This means that just like phosphate rock

Table 1. Struvite Currently Produced by Various Techniques, Including Elemental Composition

\begin{tabular}{|c|c|c|c|c|}
\hline & $\% \mathrm{P}_{2} \mathrm{O}_{5}$ & $\% \mathrm{~N}$ & $\% \mathrm{MgO}$ & source \\
\hline $\begin{array}{l}\mathrm{MgNH}_{4} \mathrm{PO}_{4} \cdot 6 \mathrm{H}_{2} \mathrm{O} \\
\text { (theoretical values) }\end{array}$ & 28.9 & 5.7 & 16.4 & \\
\hline \multicolumn{5}{|c|}{ obtained by crystallization } \\
\hline PHOSNIX $^{6}$ & 30.5 & 5.3 & 19.1 & liquor \\
\hline AirPrex ${ }^{6 a}$ & $19.8-22.9$ & $3.0-5.0$ & 10.2 & liquor \\
\hline Pearl $^{6 b}$ & 28 & 5 & $16.7-17$ & liquor \\
\hline Struvia $^{6}$ & $28-29$ & $4.5-5.5$ & $15.8-16.8$ & liquor \\
\hline NuReSys ${ }^{6}$ & $26.5-27.8$ & $5.1-5.5$ & $15.3-23.4^{c}$ & liquor \\
\hline ANPHOS $^{6}$ & 14.7 & 2.0 & 7.6 & liquor \\
\hline REPHOS $^{7}$ & 24.9 & 4.7 & 13.6 & liquor \\
\hline \multicolumn{5}{|l|}{ obtained by leaching } \\
\hline Gifhorn $^{6}$ & $25.2-36.7$ & 0.18 & $3.1-14.3$ & sludge \\
\hline Stuttgart $^{6}$ & $25.9-59.6$ & $1.2-5.0$ & $10.9-13.3$ & sludge \\
\hline PHOXAN $^{8}$ & 26.8 & 5.1 & & sludge \\
\hline Leachphos ${ }^{6}$ & $20-40$ & & & ash \\
\hline
\end{tabular}

${ }^{a}$ Related to WWTP influent. ${ }^{b}$ Moisture content of $14.9 \%$. ${ }^{c}$ Formation of magnesium phosphate phases other than struvite.

deposits that contain impurities (e.g., fluorine, cadmium, uranium, radium, mercury, lead, chromium, zinc, iron, copper, and rare-earth elements) also recovered, secondary phosphates from urban mines have variable quality and can contain undesired substances (e.g., pharmaceuticals, pathogens, and other micropollutants) that need to be considered before reuse becomes viable. ${ }^{5}$

Last year, Chen et al. published a research article in Environmental Science \& Technology entitled "Application of Struvite Alters the Antibiotic Resistome in Soil, Rhizosphere, and Phyllosphere", 9 which contained, in our view, some striking generalizations. The authors conclude that the application of struvite can facilitate the spread of antibiotic resistance into the human food chain. Since the EU included phosphates on its critical raw materials list and desires the local recovery and recycling of phosphates, these conclusions created considerable attention. On the 19th of April 2018, the European Commission published a News Alert entitled "Antibiotic resistance in struvite fertilizer from wastewater could enter the food chain", ${ }^{10}$ where the European Commission states that the findings by Chen et al. may be relevant for the ongoing revision of the EU Fertilisers Regulation that will also define under what circumstances struvite can be used as a component material for CE marked fertilizers. We feel that the conclusions of this specific case study by Chen et al. warrant a critical analysis before being used as a guideline.

A closer look at the article by Chen et al. shows that they used struvite produced from piggery wastewater, which, not surprisingly, contains considerable quantities of antibiotics (Supporting Information Table S1). Yet, Chen et al. show that their struvite derived from piggery wastewater also contains high amounts of antibiotics, such as four types of tetracycline antibiotics (360.1-742.07 $\mathrm{mg} / \mathrm{kg}$ struvite; Table 2). This is striking since related studies show that the incorporation of impurities in the struvite formed is much lower. For example, Ye et al. ${ }^{11}$ analyzed struvite precipitated from piggery wastewater, but in their case this resulted in much lower concentration levels of several antbiotics (see Table 2). This raises questions on the methodology used by Chen et al. and, in particular, the process they applied to produce struvite, which unfortunately is not described in their paper.

Interestingly, struvite produced from municipal wastewater, currently the main source for struvite production $(75 \%$, the remaining $25 \%$ comes from industrial wastewater, mainly food processing), ${ }^{12}$ contains hardly any of these impurities and the concentration of all measured substances are below any health or environmental limits calculated with the acceptable daily intake limits (Table 2). The sheer amount of antibiotics in the recovered struvite in the Chen study could well have affected the antibiotic resistance in the soil to which it was applied, but this is not the case with the analyzed struvite by Ye et al. and from municipal wastewater. Therefore, the conclusion of Chen et al., that struvite when applied as a fertilizer can facilitate the spread of antibiotic resistance into human food chain should not be applied to all types of struvite.

\section{CONCLUSIONS}

Mined phosphate rock, the primary source of phosphorus-based fertilizers, has its challenges due to toxic and radioactive elements, such as cadmium and uranium, that naturally occur in phosphate rock deposits and can be transferred into fertilizers

Published: November 21, 2018 
Table 2. Antibiotics Found in Struvite from Piggery Wastewater and Municipal Wastewater, see also Table S2 in the Supplementary Information

$\begin{array}{lccc} & \begin{array}{c}\text { Struvite Chen et al. from } \\ \text { piggery wastewater }(\mathrm{mg} / \mathrm{kg})^{9}\end{array} & \begin{array}{c}\text { Struvite Ye et al. from piggery wastewater } \\ \text { by using a fluidized bed }(\mathrm{mg} / \mathrm{kg})^{11}\end{array} & \begin{array}{c}\text { AirPrex struvite from } \\ \text { municipal wastewater } \\ (\mathrm{mg} / \mathrm{kg})^{a}\end{array} \\ \begin{array}{l}{ }^{11} \\ \text { tetracycline }\end{array} & 415.21 & 0.3-2 & <0.005 \\ \text { oxytetracycline } & 360.1 & 0.5-2 & <0.005 \\ \text { Chunicipal wastewater }(\mathrm{mg} / \mathrm{kg})^{b}\end{array}$

${ }^{a}$ One sample; detection limit of $0.005 \mathrm{mg} / \mathrm{kg},<0.005 \mathrm{mg} / \mathrm{kg}$ means not detected. ${ }^{b}$ Four samples; detection limit of $0.01 \mathrm{mg} / \mathrm{kg},<0.01 \mathrm{mg} / \mathrm{kg}$ means not detected.

and further accumulate into the soil. Similarly, recovered, secondary phosphates have their challenges too concerning pollutants from their (waste) sources. Notwithstanding, the use of secondary phosphates is essential for obtaining a circular phosphorus economy. Therefore, it is crucial that the quality of the renewable fertilizers should be guaranteed and the risk minimized. Currently, organic fertilizers are used on large scale, including the spreading of sewage sludge and manure on arable land. ${ }^{13}$ These phosphate sources are undoubtedly less clean and safe to use than the majority of recovered phosphates in struvite. This clearly unveils the need for standardized analytical methods and quality assurance (e.g., ISO standardization) as well as appropriate policy measures for struvite and all other recovered phosphates, which will bridge the gap between phosphate recovery and recycling enabling the safe and sustainable (re)use of phosphorus.

\author{
Marissa A. de Boer* ${ }^{*}+$ (i) \\ Christian Kabbe \\ J. Chris Slootweg*,† \\ ${ }^{\dagger}$ Van 't Hoff Institute for Molecular Sciences, University of \\ Amsterdam, Science Park 904, PO Box 94157, 1090 GD \\ Amsterdam, The Netherlands \\ ${ }^{\ddagger}$ P-REX® Environment, Am Goldmannpark 43, Berlin \\ 12587, Germany
}

\section{ASSOCIATED CONTENT}

\section{S Supporting Information}

The Supporting Information is available free of charge on the ACS Publications website at DOI: 10.1021/acs.est.8b03524.

(PDF)

\section{AUTHOR INFORMATION}

\section{Corresponding Authors}

*(M.A.d.B.) E-mail: m.a.deboer@uva.nl.

*(J.C.S.) E-mail: j.c.slootweg@uva.nl.

\section{ORCID $\odot$}

Marissa A. de Boer: 0000-0001-7511-887X

J. Chris Slootweg: 0000-0001-7818-7766

\section{Notes}

The authors declare no competing financial interest.

\section{REFERENCES}

(1) Ohtake, H.; Tsuneda, S. Phosphorus Recovery and Recycling; H. Ohtake, S. T., Ed.; Springer: Singapore, 2018.
(2) Steffen, W.; Richardson, K.; Rockström, J.; Cornell, S. E.; Fetzer, I.; Bennett, E. M.; Biggs, R.; Carpenter, S. R.; De Vries, W.; De Wit, C. A.; et al. Planetary Boundaries: Guiding Human Development on a Changing Planet. Science (Washington, DC, U. S.) 2015, 347 (6223), 347.

(3) de Boer, M. A.; Hammerton, M.; Slootweg, J. C. Uptake of Pharmaceuticals by Sorbent-Amended Struvite Fertilisers Recovered from Human Urine and Their Bioaccumulation in Tomato Fruit. Water Res. 2018, 133, 19-26.

(4) Ahmed, N.; Shim, S.; Won, S.; Ra, C. Struvite Recovered from Various Types of Wastewaters: Characteristics, Soil Leaching Behaviour, and Plant Growth. L. Degrad. Dev. 2018.292864

(5) Kemacheevakul, P.; Chuangchote, S.; Otani, S.; Matsuda, T.; Shimizu, Y. Effect of Magnesium Dose on Amount of Pharmaceuticals in Struvite Recovered from Urine. Water Sci. Technol. 2015, 72 (7), 1102.

(6) P-REX. Main P-REX deliverables https://zenodo.org/record/ 242550\#.WzEFPKczZdj (accessed June 25, 2018).

(7) Lebek, M.; Lohmar, S. Nährstoffrückgewinnung in Der Lebensmittelverarbeitung - Das REPHOS® Verfahren. Remondis Aqua. 2013.

(8) Egle, L.; Rechberger, H.; Zessner, M. Overview and Description of Technologies for Recovering Phosphorus from Municipal Wastewater. Resour. Conserv. Recycl. 2015, 105, 325-346.

(9) Chen, Q. L.; An, X. L.; Zhu, Y. G.; Su, J. Q.; Gillings, M. R.; Ye, Z. L.; Cui, L. Application of Struvite Alters the Antibiotic Resistome in Soil, Rhizosphere, and Phyllosphere. Environ. Sci. Technol. 2017, 51 (14), 8149-8157.

(10) European Commission. Antibiotic Resistance in Struvite Fertiliser from Waste Water Could Enter the Food Chain. Sci. for Environ. Policy 2018, DOI: 10.1021/acs.est.7b01420.

(11) Ye, Z.-L.; Deng, Y.; Lou, Y.; Ye, X.; Chen, S.; Ye, Z.-L.; Deng, Y.; Lou, Y.; Ye, X.; Chen, S. Occurrence of Veterinary Antibiotics in Struvite Recovery from Swine Wastewater by Using a Fluidized Bed. Front. Environ. Sci. Eng. 2018, 12 (3), 7.

(12) Based on our analysis there are currently 82 struvite precipitator installations operational worldwide, of which 61 are located at municipal wastewater treatment plants and 21 at industrial wastewater treatment plants, with a total production of 32.000 tonne struvite/year.

(13) For more information on the spread of antibiotic resistance genes to the soils with the use of manure, se (a) Xie, W. Y.; Shen, Q.; Zhao, F. J. Antibiotics and Antibiotic Resistance from Animal Manures to Soil: A Review. Eur. J. Soil Sci. 2018, 69 (1), 181-195. (b) Heuer, H.; Schmitt, H.; Smalla, K. Antibiotic Resistance Gene Spread Due to Manure Application on Agricultural Fields. Curr. Opin. Microbiol. 2011, 14 (3), 236-243. For more information on the spread of antibiotic resistance genes to the soils with the use of manure and biosolids, see (c) Munir, M.; Xagoraraki, I. Levels of Antibiotic Resistance Genes in Manure, Biosolids, and Fertilized Soil. J. Environ. Qual. 2011, 40 (1), 248. 